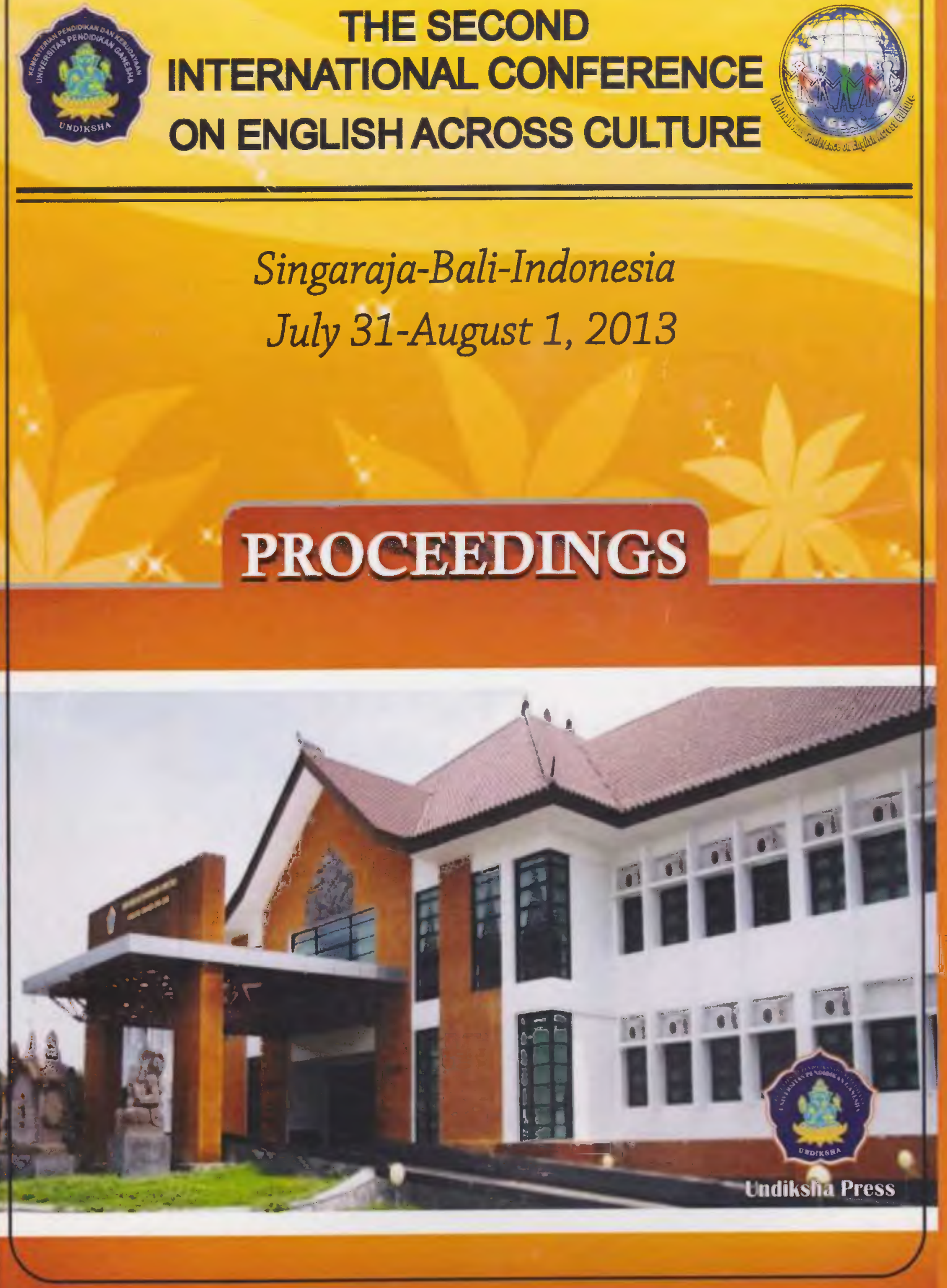




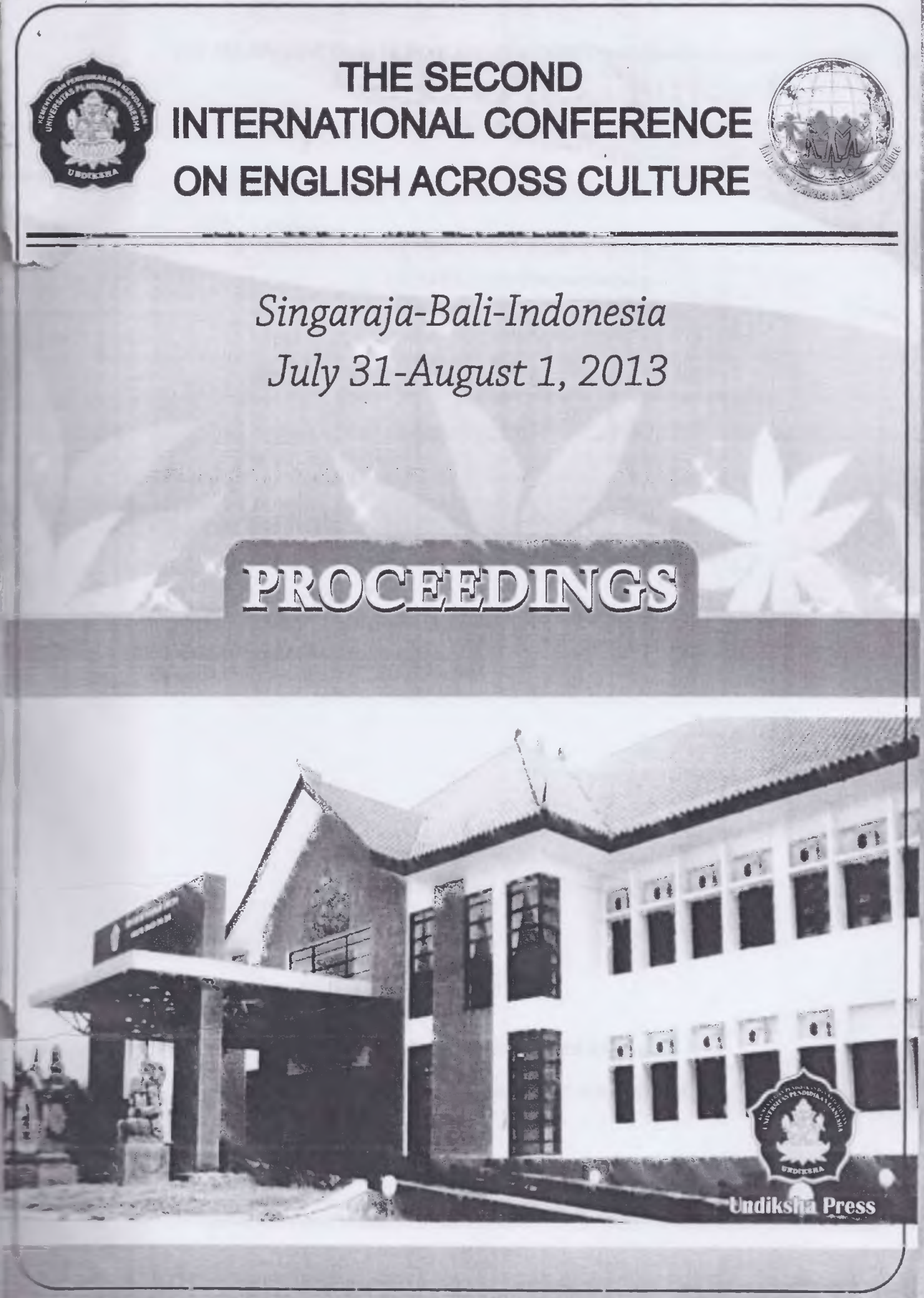


IHE SECOND INTERNATIONAL CONFERENCE ON ENGLISH ACROSS CULTURE

JULY 31 - ALGUST 1, 2013

CONFERENCE PROCEEDINGS

Edirors:

D.: L abt wh Artini, M.A., Ph.D.

Dr. I Gede Budasi, M.Ed.

Puiv Suarcaya, S.Pd., M.Sc.

1 M... Su:a taramarta, S.Pd., M.Hum.

I Nyonxan i’asek Hadisaputra, S.Pd., M.Pd.

HACLTY OF IANGUAGES AND ARTS

GANESHA UNIVERSITY OF EDUCATION

2ni Lnternational Conference on English across Culture 
INIERNATIONAL, CONFERENCE ON ENGLISH ACROSS CULTURE PROCEEDINGS

Faculty of Languages and Arts, Ganesha University of Education

Faculty of J anguages and Arts

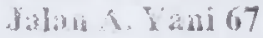

Singaraja

Email: undiksha.iceac(agmail.com

lelp: +0236221541

This book is copyright protected. No part of this publication may be reproduced, stored in a retrieval syctem, or transmitted in any form or by any means, electronic, mechanical, photucopying, recording or otherwise, without prior permission of the copyright owner.

First published in October 2011

Editors: Dia. Luh Putu Artini, M.A., Ph.D., Dr. I Gede Budasi, M.Ed. and Putu Suarcaya, S.Pd., M.isc

1,ayout: Putu Suarcava

Cover alsing: Putu Hendra

ICE $1 C$ Procedings is published by Undiksha Press, Ganesha University of Education. Series IsB $978-602-8310-74-1$

Distributed by:

Faculty of i.anguages and Arts

Jalan $A$. Yani 67

Singaraja 81116

Email: undiksha.iceacagmail.com

lelp: +6236221541

Fax: +6236225735 
Emencruting Paraphrasing Technique..

1. A Kna Purnamika Utami

Mulicultual folktales in English Language Teaching: Promoting Commonality in Diversity 13

Nvomis: Karina Wedhanti

Preparing International Standar Based Teacher Case Study: at Business Administration Study

Program, Bali State Polytechnic

1 Marle Ardana Putra. ....

Facing Communication Across Culture:

How Indonesian Interjections are Translated into English.

I (justi Agung Sri Rwa Jayantini

Phonological Processing of Dawan Language (Bd) at Words and Synphon Level (Studies of

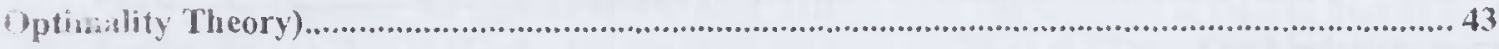

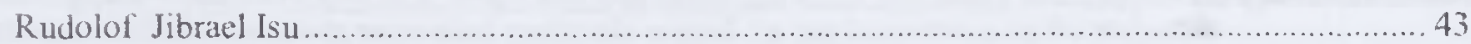

Moral Values as Reflected in English and Indonesian Proverbs ................................................ 55

A

The Authenticity of English Assessment in Senior High Schools.................................................. 61

I Gusti Ayu Putu Novita Sari Paragae ................................................................................. 61

Direct I ransiation Tech mique of Teaching English Songs for Sunday School Students ............. 73

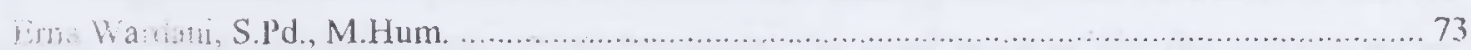

Rejaming A ththentic Materials for Teaching Grammar: Practicing Grammar In Context...... 85

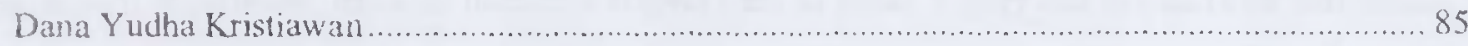

Prolessionally Character-Loaded English Teaching and Learning: An Indonesian Nexus......... 89

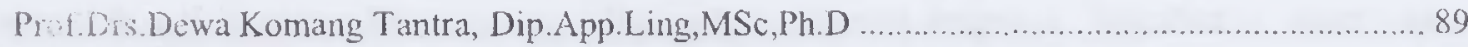

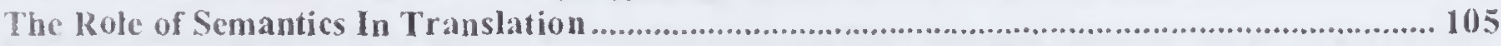

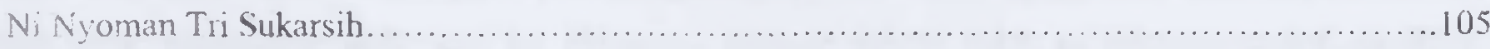

Selopting Democratic Approach in English Teaching ............................................................. 116

I Gde Putu Agus Pramerta .................................................................................... 116

Stadents' Perception of Essay Test (A Case Study at the Third Grade Students of English

Departement of School of Higher Learning Pasundan Cimahi) ................................................ 136

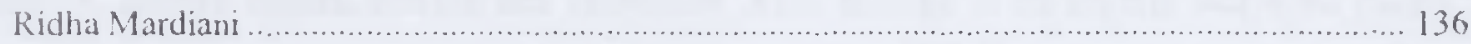

Developing an Ethnopragmatic Script For Balinese Active Metaphor (Behlabadan).............. 1477

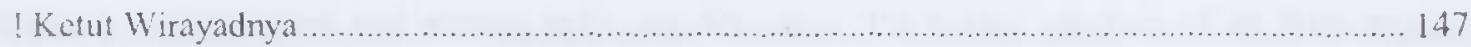

Jazz Chants, Drills and Total Physical Response In Teyl......................................... 16060

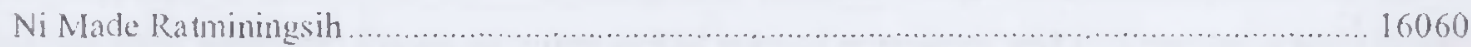

Inventing Character Values in Prose Fiction Creative Process .............................................. 1777

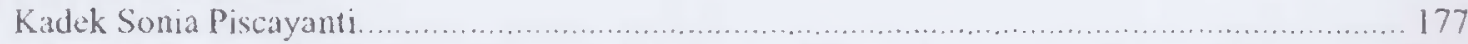

You Just Can't Understand until I Tell You: Conflict Naratives and Identity ......................... 189

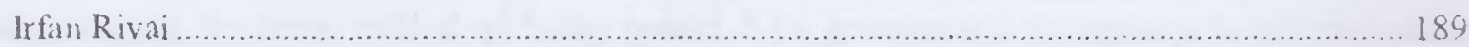

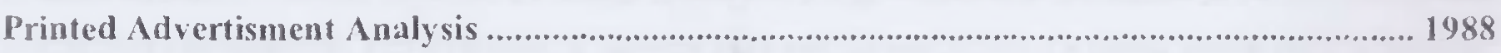

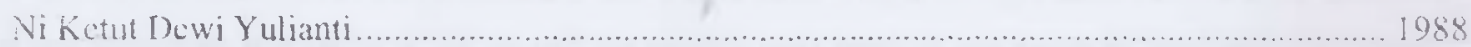
ieaching Japanese English in Bali: Integrating Balinese and Japanese Cultures within English l.anguage Teaching 


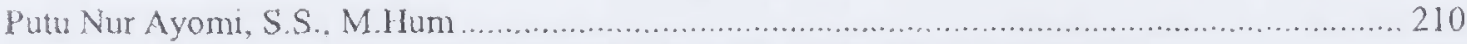

Taking Reading Into Active Skill: $\mathbf{A}$ Research On Reading-Class Activities......................... 220

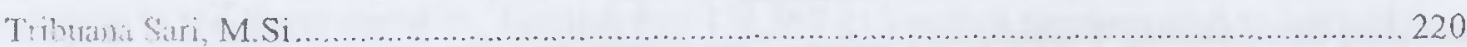

Trpes OI Teacher Questions In Efl Classroom Activities............................................... 230

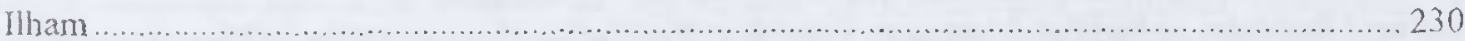

Needs Analysis On Developing A Toefl-Based Learning Center (Lc): An Implementation of Self-

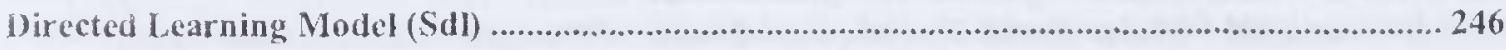

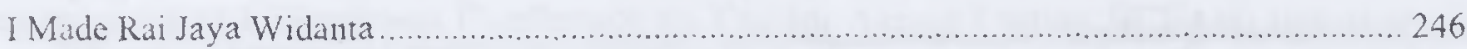

A Contextual Approach: Business Presentation to Accelerate EFL, Learners' English Speaking

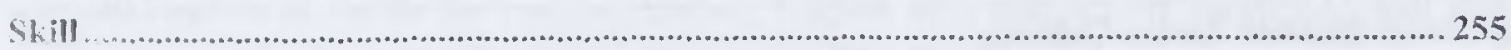

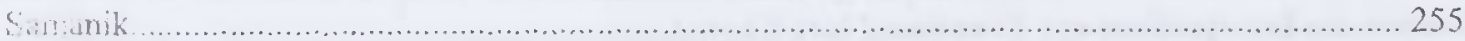

Interesting Learning Activities from Scrap Papers: Putting Eco-pedagogy into practice ........ 264

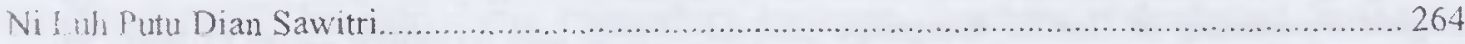

Chobatiration of Public Education System: Key factors for success...................................268

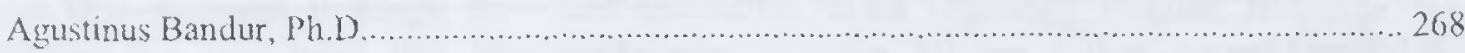




\title{
TYPES OF TEACHER QUESTIONS IN EFL CLASSROOM ACTIVITIES
}

\author{
Ilham \\ University of Muhammadiyah Mataram \\ Ilham_Mataram@yahoo.com
}

\begin{abstract}
This paper will report types of question the teachers usually use in EFL classroom. This study adopted a qualitative approach as it involved the collection and qualitative analysis of data. This study also has a characteristic of case study because it was carried out in "a small scale, a single case" (Stake, 1985:278 as cited in Emilia, 2005:74). This study was conducted in English Deparment students Muhammadiyah university of Mataram. There were two main techniques used to collect data in this study namely observation and video recording. The observation was conducted to identify teachers' question, while the video recording was utilize to capture many details of lesson that cannot easily be observed. In analyzing the data the researcher made the description, transcription, and classification of the utterances into teacher question category. This study reveals that epistemic questions are more dominant than echoic questions.
\end{abstract}

Keywords: types of teacher questions, EFL classroom

\section{A. Introduction}

In classroom, teacher plays very important roles. The teacher can be as controller, director, facilitator and resource (Brown, 2001: Harmer, 1991, 2001, 2007). The teacher roles will affect the quality and the quantity of input, output, and interaction in the classroom. Input can be provided in good quality and sufficient in amount if the teacher contribute maximally in the role of resource from teacher talks (Ellis, 1986; Chaudron, 1988; Nunan, 1991) in explaining, commenting, or even questioning during the classroom activities. Language production as the intended output can also be triggered by teacher when he/she carrying out the role of controller by giving commands or questions to the students in the classroom. Interaction as the core of teaching and learning process and through it acquisition can be maximized through the conversation between teacher and students in which questioning-answering dialog pattern is commonly adopted (Long, 1981;Ellis, 1986;Johnson, 2001;Brown, 2001).

Questioning has always been acknowledged as the stock-in-trade of classroom teachers and fundamental to outstanding teaching (Klein, Peterson, \&Simington, 1991 in Hussin, 2006). Effective questioning by the teacher is believed to focus students' attention to understand lesson content, arouse their curiosity, stimulate their imagination, and motivate them to seek out new knowledge (Durham, 1997 in Cakmak, 2009). Moreover, questioning is a skill which enables one to discover the hidden treasure of knowledge (Farmer, 2006 in Nisa \& Ahmad Khan, 2012; ). Therefore, if used well it can make a significant contribution to improve teaching and learning.

Regarding the importance of teacher questions in language learning, teacher should know what kinds of questions which are potential to support students in learning a target language. The emergency of knowing types questions are based on the reason that certain sort of questions will likely trigger the students to respond in more complex answer, provide more comprehensible input, and create more genuine interaction.

However, being familiar with the type of questions only is not sufficient to conduct effective teaching. Students as the addressee of teacher questions sometimes or even very often do not understand what the answers of the questions are. Hence they cannot give response. To overcome this problem teacher usually will modify their questions through negotiation of meaning in form of 
simplifying, redirecting, paraphrasing (Chaudron, 1988), or even translating the question into students' first language (L1) in such way the students are expected to give responses more easily.

In EFL classrooms, by giving students questions teachers are able to elicit utterances from students and provide opportunity to keep students talking during the classroom activities. In this regard, teacher's questions will both provide important exposures to support student familiarity on English usage and chances to test their understanding on certain features of English they have learnt. In this context, teacher's questions functions as medium of interaction between students and teacher verbally in which they share and exchange information about English based on the materials used during the learning process. This verbal exchange plays an important role in classroom language learning for students to acquire the language faster and more natural.

There is a wide range of research on types of teachers' questioning in the teaching process. First, Hassan Qashoa (2013 ; Behnam and Pouriran (2009), for instance, investigated types of teacher questions and their impact on classroom interaction. This studies revealed that display question are used more frequently than referential one, and high frequencies of wh questions were found in the three investigated classess. Second, Adibah (2011) did analysis of questions used by an english teacher in classroom. The finding showed that the teacher performed six out of seven question types proposed by Brown (2007), including: knowledge, comprehension, application, inference, analysis, and synthesis questions. In this study, knowledge questions were used to elicit factual answer, recall tests, recognize information, and check students understanding. Comprehension questions were utilized to translate words from Indonesian to English, and vice versa. Application question were employed to ask the students to spell and pronunce words so that the students understood the differences.

The next researchers is Ruby Yang (2012) investigated the types of question asked by the three NN pre-service English teachers teaching in three different bands of secondary schools. This study shows that in all the three lessons, yes/no questions, and closed and display questions were frequently asked by the teachers, while open and referential questions were rarely or even never asked. In addition, Roostini (2011) analyzed questioning types used by three teachers of general English classes. The result showed that referential questions were more frequently used than display questions at higher levels. Moreover, Inan \& Fidan, (2012) also explored the questioning practices in a lower secondary co-education social studies classroom. The finding of this study indicated that the majority of the questions in the data set belong to epistemic questions and under the title of epistemic questions; the most commonly used question type is display questions and under the title of echoic questions; the most commonly used question type is confirmation checks. Another researcher in teacher questioning is done by

All mentioned above indicates that effective questioning is a skill that every teacher should develop as also stated by Capel et al (1996) in Cakmak, (2009). Teacher can sharpen their questioning skills by becoming familiar with different types of questions in order to help students think more crtically ad creatively.

Realizing the important role of teachers' questions, the types of questions and their essential functions, this study aims to investigate the type of questions provide by teacher or lecturer in the second semester of English Department UM Mataram.

This study is conducted to find out the answer of the following research questions:

1. What type of question do the teachers usually use in EFL classroom?

\section{B. REVIEW OF RELATED LITERATURE}

This section will discuss the theories underpinning the study, especially in analyzing the purpose of questioning, the function of questioning, teacher questions and classroom second language learning, and types of teacher questions 


\subsection{The Purpose of Questioning}

In classroom, teacher ask questions are based on several purposes. They ask questions on the purposes of managing the class, engaging the students with the content, encouraging participation and increasing students' understandings (Darn, 2008). Similarly, Brown and Edmunson, 1984:100 cited in Cakmak, 2009) states that teacher ask questions to arouse interest and curiosity concerning a topic; to focus attention on particular issue or concept; to develop an active approach to learning; to stimulate pupil to ask questions of themselves and others; to structure a task in such a way that learning will be maximized; to diagnosed specific difficulties inhibiting people learning; communicate to the group that involvement in the lesson is expected; to provide an opportunity for pupils to assimilate information; to involve pupils in using and inferred cognitive operation; to develop reflection and comment by pupils on the responses of teacher or students; to afford an opportunity to learn through discussion and to express a genuine interest in the ideas of feeling of the pupils.

In accordance with the previous purposes, Chun-Miao (2007) afforms that teacher give question during the classroom activities at the aims at 1) letting students to present information like facts, idea, opinion;2) making examination about learners understanding, knowledge or skills;3) engaging learners actively in participating their learning; 4) stimulating thinking or probing more deeply into issues; and 5) getting students to review and practice previously learnt materials.

In addition, Cotton (1988) reports a variety of purposes emerge from analysis of the literature, including: to develop interest and motivate students to become actively involved in lesson; to evaluate students preparation and check on homework or seatwork completion; to develop critical thingking skills and inquiring attitudes; to review and summarizes previous lessons; to norture insights by exposing new relationship; to assess achievement of instructional goals and objectives; to stimulate students to pursue knowledge on their own. Furthermore, more explicit judgement was coined by Paul and Elder (2007c in Akmaludin, 2009) that "socratic questions " can be used to stimulate students think critically.

\subsection{The Function of Questioning}

By adapting the function of questions proposed by Kinsella (1991), Brown (2001) adds that in language classroom, questioning 1) can give the students the impetus and opportunity to produce language comfortably without having to risk initiating language themselves, 2) can serve to initiate a chain reaction among themselves, 3) give the instructor the immediate feedback about students comprehension, and 4) provide students with opportunities to find out what they think by hearing what they say.

The functions of teacher questions in classroom are also described more specifically by Xioyan (2006 cited in Donald \&Eggen's (1989). He describes that classroom questioning can serve three strategic functions; diagnostic, instructional and motivational functions. As diagnostic function, teacher can address questions to check what students know, what they don't know, how they think about material being presented.

The second function that teacher perform is instructional function. This function emphasizes on the role that questions serve in assisting students to learn new material and integrate it with the old one. For this purpose, teacher possibly use. For this purpose teacher possibly use various type of questions such as referential or divergent questions, display questions or event rhetoric questions.

The third function of classroom question is motivational. Teacher can distribute questions at the beginning of teaching and learning process to trigger students' attention and provide a focus for the lesson. By having students attention and focus, it expected that they will involve actively in discussion, group work etc.

\subsection{Teacher Questions and Classroom Second Language Learning}

In second language classroom setting, questions have been used for a wide variety of educational purposes: reviewing previously studied material; diagnosing students abilities; stimulating critical thinking; managing students behavior; probing students thought process; stirring creative thinking; motivating students; and assessing students knowledge (Chin, 2006). 
More specifically, Darn (2008) elaborate how questioning contributes and help teachers in conducting language teaching-learning process in classroom. Firstly, teacher can use referential questions at the brainstorming stage of teaching to generate interest and topic-relate vocabulary of students. Secondly, when teacher presented material in the target language through explanation, elaboration, or giving questions, students can learn how to use the language contextually and they can make use their teacher presentation as medium for hypothesizing their concept or understanding about the language being learnt. Thirdly, by giving simple questions such as comprehension check, clarification request and confirmation check can increase the atmosphere of the classroom become more communicative. Fourthly, when teacher applies the question-answer approach, teacher can provide various kind of expossures (input) and students can have oppurunities to practice the language. Lastly, teacher can take the advantages of referential questions outside the classroom to have 'chat' with the students.

How teacher questions contribute in providing input can be illustrated as the following figure (Chun-miao, 2007).

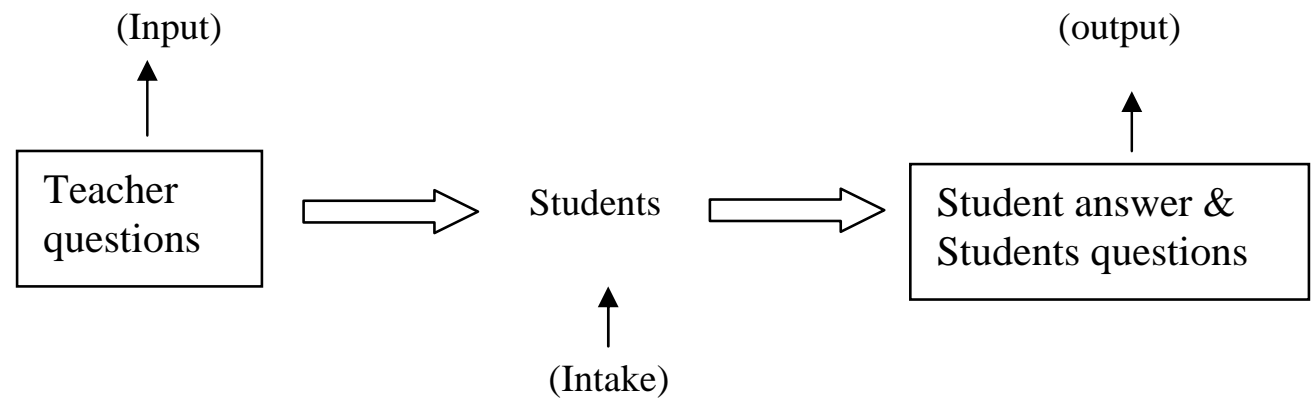

Figure 1.1: Input \& output through teacher questioning

\section{4. Types of Teacher Questions}

There are several taxonomies used to categorize type of question. Some classify questions from cognitive domain, some are from the purpose of the questions, and some other groups the question from perspective of source of information.

Among the well-known of question categories proposed by Long and Sato (Ellis, 1994; Orlich, et al. 1985 cited in Suherdi, 2009). According to them the question are divided into two categories, particularly echoic and epistemic questions. In the first category, there are three types of questions: 1) checking understanding, 2) asking clarification, and 3) asking confirmation. While in second category consist of four types: 1) referential question, 2) display question, expressive question and 4) rhetoric question.

Similarly, the well-known taxonomy of questions based on cognitive was proposed by Benyamin S. Bloom 1956. He explains that the questions are devided into six level. The first level is questions which need to recall knowledge, the second level is comprehension, and the third is application, the fourth is analysis, the fifth is synthesis and the sixth is evaluation. The following table will show some samples of question which belong to each level of cognitive domain.

Table 01: Bloom's Question Taxonomy

\begin{tabular}{|l|l|l|}
\hline No & Category & Sample Questions \\
\hline 1 & Knowledge & $\begin{array}{l}\text { Who discovered The Mississippi River? } \\
\text { What word doesan objective modify? } \\
\text { What is the best method of concluding? }\end{array}$ \\
\hline 2 & Comprehension & $\begin{array}{l}\text { How do democrat and republicans differ in their views? } \\
\text { Given the present populations what will be the world population by } \\
\text { the year 2500? }\end{array}$ \\
\hline 3 & Application & How has the Miranda decision affected civil liberties? \\
\hline
\end{tabular}




\begin{tabular}{|l|l|l|}
\hline 4 & Analysis & $\begin{array}{l}\text { Who can distinguish between fact and opinion in the article we } \\
\text { read? } \\
\text { How do Picaso organize color, shapes, and sizes to produce } \\
\text { images? }\end{array}$ \\
\hline 5 & Sythesis & $\begin{array}{l}\text { What are the common causes for cell mutations cancer, and aging? } \\
\text { How would you go about determining the chemical weight of } \\
\text { unknown substance? }\end{array}$ \\
\hline 6 & Evaluation & $\begin{array}{l}\text { Who can judge what is wrong with the architect's design of } \\
\text { plumbing and electricity? }\end{array}$ \\
\hline
\end{tabular}

Adapted from Ornstein (1987:74)

Besides, Barnes (in Ellis, 1994: Tsui (1995) in Ruby Yang, 2010) developed taxonomy of questions into four different types of questions. The first type is questions concerning factual matters, that is, the question beginning with "what". The second type is question of inference beginning with "how" and "why". The third type is open questions which do not require any inference. And the last type is question for communication, which could affect and control the behavior of learners. Barnes further classified the second type into closed questions and open questions. Questions are closed because there is only one existing answer, while to open questions there is more than one answer.

Furthermore, Richard and Lockhart (1997: 186) classify questions into three categories in terms of the purpose of questions in classrooms; procedural, convergent, and divergent. Procedural question have to do with classroom procedures and routines and classroom management. They are used to ensure the smooth flow of the teaching process. Unlike procedural questions, many of questions teacher ask, such as convergent and divergent questions, are designed to engage students in the content of the lesson, to facilitate their comprehension, and to promote classroom interaction. Convergent questions encourage similar students responses. These responses are often short answers, such as "yes" or "no" or short statements. They do not usually require students to engage in high level thinking in order to come up with a response but often focus on the recall of the preciously presented information. Divergent question are quite different from convergent questions. These questions encourage diverse student response which are not short answer and which require students to engage in higher-level thinking. They encourage students to provide their own information rather than recall previously presented information.

Long and Sato (in Ellis, 1994) proposed categories of questions based on whether or not the questioners have already known the answers. The categories are" display" and "referential" questions. Display questions refers to that teachers know the answer and which are designated to elicit or to display particular structures. For example, 'what is the opposite of up in English?' On the contrary, referential questions or "genuine questions (Thornbury, 1996) refers to the questions that the teacher do not know the answer to, and can gain various subjective information. For example, 'why don't you do your homework?'

Beside display and referential questions, they also proposed types of question based on the function of the questions. Comprehension check (e.g. All right?, OK?) is used to determine whether the other speaker has understood a preceding message, clarification request (e.g. what do you mean?) is used to seek assistance in understanding the other speaker's preceding utterances through questions, and confirmation check (e.g. carefully?) is used to seek confirmation of the other's preceding utterance through repetition, with rising intonation, of what was perceived to be all or part of the preceding utterance (Pica, 1987).

With the equal category, Eng Ho (2005) classifies types of teacher questions into two categories, display or close questions and open or referential questions, based on the communicative impact which generate from the answer of the questions. If the questions require lengthy and complex answers, the questions are included into referential questions. The display questions are the questions which need restrict and closed answer.

\section{Methodology}

This study was conducted by applying qualitative research design in which the researcher as the main instrument collected data by observing the natural setting of the classroom interaction. In 
this sense, this research is also called "naturalistic inquiry (Lincoln \&Guba, 1985; Nunan, 1992; Cohen \& Manion, 1994; Meriam, 1998; Silverman, 2005; Alwasilah, 2008). Naturalistic inquiry refers to that the teacher tries not to intervene in the research setting and does not try control naturally occurring event, because the researcher wishes to describe and understand the process rather than the test specific hypotheses about cause and effect relationship.

In this investigation the researcher use case study method. Then this study is qualitative case study which was characterized as being "particularistic, descriptive, and heuristic" (Meriam, 1998:29).

Based on the characteristic of qualitative case study, it was reasonable for this writing to investigate teachers' questioning in EFL classroom in-depth to understand the process of questioning in classroom setting holistically, to focus the investigation particularly on the types of the teacher question and to give complete issues of questioning in EFL classroom.

This study was conducted in second semester students of English Department UM Mataram. The reason for choosing this campus was the accessibility of the researcher into the research place. There is one class as the participant of the study particularly class $C$ which consist of 30 students. To get the data of teachers questioning, this study involves participant observer that the writers himself as a teacher.

There were two main techniques used to collect data in this study namely observation and video recording. The observation was conducted to identify teachers' question, while the video recording was utilize to Capture many details of lesson that cannot easily be observed (Richard and Lockhart, 1994).

In analyzing data from observation and video recording, the researcher made description of each observation based on the notes taken during the observation. After having description, the next step was transcribing the data from video-recording. After having transcription, then the researcher classified the utterances into teacher question category. The category are display question, referential question, comprehension check, clarification request, and confirmation check.

\section{RESEARCH FINDING AND DISCUSSION}

The result from the analysis are described and discussed with the help of micro pedagogic systematic by identifying type of questions that developed by teacher and which type of question is the most dominant and its meaning for the process of teaching and learning.

\section{Preparation Exchange}

\begin{tabular}{|c|c|c|c|c|c|c|}
\hline No & GR & BT & UL & PB & PG & Activities in classroom \\
\hline 1 & & TU & & & & $\begin{array}{l}\text { T1: Before we start the class, I want to introduce myself. I am } \\
\text { here to explore about English teaching in tertiary level and I } \\
\text { am very glad now, today at this hour, we can see very cute } \\
\text { faces here. This is mid noon. How are you all? }\end{array}$ \\
\hline 2 & & $\mathrm{~TB}$ & & & & Ss: Fine, thank you. And you? \\
\hline 3 & & TB & & & & T1: Once again? How are you? \\
\hline 4 & & JL & & & & Ss: I'm fine, thank you and you? \\
\hline 5 & & JL & & & & $\begin{array}{l}\text { T1: Well, I want to introduce you to new partner. Here we have } \\
\text { it....Please let him introduce himself. (T1 plays the video of } \\
\text { "Saying Sorry" in which there is the other partner mentioned. } \\
\text { It's Mr. Duncan) }\end{array}$ \\
\hline 6 & & $\mathrm{JL}$ & & & & $\begin{array}{l}\text { T1: Well, in this occasion we are going to look at an action, which } \\
\text { for many of us, is very hard to do, "Saying Sorry". But } \\
\text { firstly, Let's see Mr. Duncan show on saying sorry. }\end{array}$ \\
\hline
\end{tabular}




\section{Explanation Exchange}

\begin{tabular}{|c|c|c|c|c|c|c|}
\hline No & GR & BT & UL & PB & PG & Activities in classroom \\
\hline 7 & & TA & & & display & $\begin{array}{l}\text { T1:So during the show, can anyone recall one expression } \\
\text { about saying sorry? Can anyone recall for one saying } \\
\text { sorry expression? }\end{array}$ \\
\hline 8 & & TB & & & display & $\begin{array}{l}\text { T1:None...None...? You enjoy Mr. Duncan more than the } \\
\text { expressions. What about the remorse? Can anyone } \\
\text { recall one of chat on remorse? The reply? None..None ..? } \\
\text { Yes..You,.. }\end{array}$ \\
\hline 9 & & JL & & & & $\begin{array}{l}\text { T1:Okey..we'll replay the expressions once again.. } \\
\text { One expression I will stop, one expression I will stop. } \\
\text { Or you want the show just go on, which one do you } \\
\text { prefer? (T plays the video. MR Duncan expression of } \\
\text { saying sorry) }\end{array}$ \\
\hline 10 & & JL & & & & $\begin{array}{l}\text { T1: We walk on banana skin, we drop on the banana ...pile } \\
\text {..we drop for the banana skin...and some one says sorry } \\
\text {..see you then..hahaha..you can say sorry but hahaha } \\
\text { right..that's for sympathy....something for sympathy. }\end{array}$ \\
\hline 11 & & TB & & & confirm & $\begin{array}{l}\text { T1: Can anyone recall one expression of saying sorry? } \\
\text { Ok..You... }\end{array}$ \\
\hline 12 & & $\mathrm{JL}$ & & $\mathrm{C} 1$ & & S1 : I am terribly sorry for what I said to you. \\
\hline 13 & & TB & & & Comp & T1 : Good, another? \\
\hline 14 & & $\mathrm{JL}$ & & C1 & & S2 : I realize my mistake now and I'm sorry. \\
\hline 15 & & TB & & & Comp & $\begin{array}{c}\text { T1 : Good, another expression... different expression? For } \\
\text { expressing remorse..remorse...reply.... }\end{array}$ \\
\hline 16 & & KaJ & & C1 & & $\begin{array}{l}\text { S3 : for reply...for the expression of reply...Ehm... That's } \\
\text { quite alright, I forgive you. }\end{array}$ \\
\hline 17 & & KaJ & & & & T1 : Perfect \\
\hline 18 & & JL & & C1 & & S4 : Hey...I'm sorry too. \\
\hline 19 & & KaJ & & & & T1 : right \\
\hline 20 & & $\mathrm{JL}$ & & C1 & & S5 : Yes I forgive you. \\
\hline 21 & & TB & & & comp & T1 : Other? \\
\hline 22 & & $\overline{J L}$ & & C1 & & $\begin{array}{l}\text { S6 : So ..we..are ... friend....again? (Student's expression } \\
\text { is not clear) }\end{array}$ \\
\hline 23 & & SA & & & & $\begin{array}{l}\text { T1 : (approaches the students) I can just see your eyes...let } \\
\text { me hear your voice...come on be confident }\end{array}$ \\
\hline 24 & & $\mathrm{JL}$ & & C1 & & $\begin{array}{l}\text { S6 : So we are friends again ( student says the expression } \\
\text { in clear voice) }\end{array}$ \\
\hline 25 & & TU & & & display & $\begin{array}{l}\text { T1 : In this opportunity, in this occasion, in this time would } \\
\text { you, one or two, say sorry to your friends... Raise your } \\
\text { hands......Blink your eyes. If you shy to raise your } \\
\text { hand...just blink your eyes... and I will come to you. Do } \\
\text { you know what I want you to do? }\end{array}$ \\
\hline 26 & & JW & & & & S1 : Saying sorry for friends \\
\hline 27 & & $\mathrm{JL}$ & & & & Ss $:$ Yes... \\
\hline 28 & & $\mathrm{JL}$ & & & & $\begin{array}{l}\text { T1 : Yes, saying sorry for friends .in your class } \\
\text { here... Maybe by no means you took your friend's pen.. }\end{array}$ \\
\hline 29 & & KaJ & & C1 & & $\begin{array}{l}\text { S4 : For my friends, I'm sorry for my mistakes ..for } \\
\text { everything I did...because I made many mistakes.. }\end{array}$ \\
\hline 30 & & TU & & & display & $\begin{array}{l}\text { T } 1 \text { : Do you think so that your beautiful friend here made } \\
\text { mistake? }\end{array}$ \\
\hline
\end{tabular}




\begin{tabular}{|l|l|l|l|l|l|l|}
\hline 31 & & JW & & & & Ss : no... \\
\hline 32 & & JL & & C1 & & S 3 : For my friends I am very sorry for what I did.. \\
\hline 33 & & KaA & & & & T1 : Good \\
\hline 34 & & JL & & display & $\begin{array}{l}\text { T 1 : About some expressions you can use when you are a } \\
\text { professional, working type, like you are saying sorry } \\
\text { for your customer. it's impossible that you are saying } \\
\text { sorry to you customer by saying "sorry" (with weak } \\
\text { and sexy tone) }\end{array}$ \\
\hline
\end{tabular}

\section{Discussion of Teaching Material (advance) Phase}

\begin{tabular}{|c|c|c|c|c|c|c|}
\hline No & GR & BT & UL & PB & PG & Activities in classroom \\
\hline 35 & & JL & & & & $\begin{array}{l}\text { T1 : (Read the expression of saying sorry from book) } \\
\text { Those are some expressions that we can use in formal } \\
\text { circumstance or formal occasion ....very simple but } \\
\text { formal } \\
\text { Would like .....if you use would like so it's formal. } \\
\text { Okey...I'm sorry to hear that...please accept my } \\
\text { condolence..If we are friends we do not say condolence. } \\
\text { This is for occupational relation.. } \\
\text { Here is the example (Teacher reads the expressions on the } \\
\text { board) }\end{array}$ \\
\hline 36 & & SA & & & Ref & $\begin{array}{l}\text { T1 : Now. Let's have a practice on saying sorry. Please read } \\
\text { this dialogue } \\
\text { Any one want to be Edo..? Anyone want to be } \\
\text { Kuncoro.? }\end{array}$ \\
\hline 37 & & MA & & & & Ss : (read the dialogue) \\
\hline 38 & & TU & & & disp & $\begin{array}{l}\text { T1 : Very nice! } \\
\text { Ok, I guess you know the message in the conversation } \\
\text { right? You got the whole message of the conversation? } \\
\text { For the second conversation I saw the one sitting at the F } \\
\text { table.. What 's your name please? }\end{array}$ \\
\hline 39 & & $\mathrm{JL}$ & & & & S4 : Felisco \\
\hline 40 & & TU & & & Disp & $\begin{array}{l}\text { T1 : Very nice name ...it's like very sexy to say it, right? } \\
\text { It's manager and guess... who want to be the guess? Who } \\
\text { wants to be the guess? }\end{array}$ \\
\hline 41 & & $\mathrm{JL}$ & & & & S7 : me.. \\
\hline 42 & & $\mathrm{JL}$ & & & & $\begin{array}{ll}\text { S8 } & \text { : me...... } \\
\text { T1 } & \text { : you don't have the look of yes.. } \\
& \text { S7\&S8: (read the text) }\end{array}$ \\
\hline 43 & & KaJ & & & & $\begin{array}{l}\text { T1 : Yes..thank you. Dialogue number 3... It should be } \\
\text { ladies }\end{array}$ \\
\hline 44 & & TA & & & & Ss $:$ (read the dialogue) \\
\hline 45 & & TA & & & & T1 : number 4 \\
\hline 46 & & TA & & & & Ss : (read the dialogue) \\
\hline
\end{tabular}

\section{Checking Students Understanding Phase}

\begin{tabular}{|l|l|l|l|l|l|l|}
\hline No & GR & BT & UL & PB & PG & Activities in classroom \\
\hline 47 & & JL & & & & $\begin{array}{l}\text { T1 : Now we go on to some exercises....just simple } \\
\text { exercises ...Take it easy... }\end{array}$ \\
\hline 48 & & TU & & & comp & T2 : Ok....So we come up with the activity of practicing the \\
\hline
\end{tabular}




\begin{tabular}{|c|c|c|c|c|}
\hline & & & & $\begin{array}{l}\text { expressions that you have learnt about showing } \\
\text { sympathy, regret, apology. Okey before we go on with } \\
\text { the activity. Can you, one of you raise your hand, say } \\
\text { about the expressions of saying sorry? Well, I want you, } \\
\text { I would like you to say or to remember again once of the } \\
\text { expressions of saying sorry before we go on with this } \\
\text { activity? Raise your hand, and say it? Do you remember } \\
\text { Mr. Duncan expressions of saying sorry? }\end{array}$ \\
\hline 49 & JW & C1 & & S9 : I ever say sorry. \\
\hline 50 & TU & & comp & T2 : Okey, the other expression? \\
\hline 51 & JW & $\mathrm{C} 1$ & & S10 : I hope you can forgive me. \\
\hline 52 & TU & & comp & T2 : Good. What about formal expressions? \\
\hline 53 & JW & $\mathrm{C} 1$ & & S11 : I would like to sorry for being late. \\
\hline 54 & TU & & comp & $\begin{array}{l}\text { T2 : That about if you come late to school, and then you } \\
\text { wanna say sorry to your teacher, what will you say? }\end{array}$ \\
\hline 55 & JW & & & : I would like to say apology for being late to class. \\
\hline
\end{tabular}

\section{Exercise Phase}

\begin{tabular}{|c|c|c|c|c|c|c|}
\hline No & GR & BT & UL & PB & PG & Activities in classroom \\
\hline 56 & & TB & & & display & $\begin{array}{l}\text { T2 : Perfect. Any other expressions that you can create } \\
\text { by yourselves? } \\
\text { Let do the exercises, for number one. Who wants to } \\
\text { try to do number one? } \\
\text { Okey, I'll give one minute to complete the first } \\
\text { exercise. }\end{array}$ \\
\hline 57 & & $\mathrm{JL}$ & & & & : Two minutes Mr. \\
\hline 58 & & JL & & & ref & $\begin{array}{l}\text { T } 2 \text { : Okey two minutes then. } \\
\text { The second dialogue please? }\end{array}$ \\
\hline 59 & & MA & & & & $\begin{array}{l}\text { T2 : Okey, we have completed the dialogue. Now let's } \\
\text { try to act the dialogue out. }\end{array}$ \\
\hline 60 & & TA & & & & Ss : (practice the dialogue) \\
\hline 61 & & KaJ & & & & $\begin{array}{l}\text { T } 2 \text { : Perfect work. Well thank you. Now we are going to } \\
\text { have a game. }\end{array}$ \\
\hline 62 & & TU & & & Ref & $\begin{array}{l}\text { T3 : Hello everybody, are you happy? Do you understand } \\
\text { about this material? }\end{array}$ \\
\hline 63 & & JW & & & & $\mathrm{S} \quad:$ Yes... \\
\hline 64 & & $\overline{\mathrm{JL}}$ & & & & $\begin{array}{l}\text { T3 : Little..Little I know yah.. } \\
\text { I want to make a game for you all but I want you to } \\
\text { make cooperation with me? } \\
\text { Okey, you have to make a group, one group consists } \\
\text { of four students, Okey... You can choose, you can } \\
\text { turn around, and you choose your friends by } \\
\text { yourself.. } \\
\text { Okey I'll give this transcript and you can read it.. } \\
\text { You are going to have a role play...this script is jus } \\
\text { an example for you to make a dialogue with your } \\
\text { friends..and you must perform or to present your } \\
\text { dialogue in front of the class, in front of your } \\
\text { friends..it's like doing drama...just five minutes to } \\
\text { make the dialogue.. }\end{array}$ \\
\hline 65 & & $\mathrm{JL}$ & & & & : (Make the dialogue \\
\hline 66 & & JL & & & & T3 : ( Goes around the class to check the students' work.). \\
\hline 67 & & $\mathrm{JL}$ & & & & Ss : (perform the dialogue in front of the class. Three \\
\hline
\end{tabular}




\begin{tabular}{|c|c|c|c|c|}
\hline & & & & groups perform the drama in front of the class.) \\
\hline 68 & $\mathrm{JL}$ & & T3 & $\begin{array}{l}\text { : Okey, we have to finish our game, because of the } \\
\text { time. Okey....see you later guys.. }\end{array}$ \\
\hline 69 & MA & ref & T1 & : Can I have your attention please? \\
\hline 70 & KaJ & & & $\begin{array}{l}\text { : Thank you..you know this is the time for us to } \\
\text { parting ..maybe this is the only chance we can see } \\
\text { each other..we can communicate in a facebook...don't } \\
\text { forget to always use English. } \\
\text { Thank you very much for your very nice cooperation. } \\
\text { I'm really glad to see you. Thank you very much. } \\
\text { Thank you. I would like to say sorry if by no means } \\
\text { we make you uncomfortable during the class thank } \\
\text { you for your attention. Assalamualaikum wr wb have } \\
\text { a nice day. }\end{array}$ \\
\hline
\end{tabular}

\subsection{Types of Teachers' Question Data}

Data of each type will be analyzed with the help of micro pedagogic systematic by identifying type of questions that developed by teacher and which type is the most dominant and its meaning for the process of teaching and learning. The description of teachers' question types is elaborated as follows:

\section{Preparation Exchange}

In this phase teacher does checking steps for making sure that the class is ready to have teaching and learning process. There is one question in this step (utterance 3), teachers asking students condition. And students also ask their teacher condition. Then, teacher introduces herself and followed by her friends.

\section{Explanation Exchange}

This phase consist of 27 utterances which containing 14 questions particularly 5 display questions (utterance 7,8, 25, 30,34), 1 confirmation check question (utterance 11), and 3 comprehension check questions $(13,15,21)$.

\section{Advance Explanation Exchange}

In this phase teacher discusses expressions that we can use in formal circumstance or formal occasion, very simple expression but it is formal. Types of teacher questions are 1 referential question (utterance 36), 2 display questions (38 and 40).

4. Checking students understanding

In this phase teacher checking students understanding about the expression of saying sorry. Completely this phase comprise of 9 utterances which consist of 8 questions: 4 comprehension questions (utterances 48, 50, 52, 53), 3 referential questions (utterance 58, 62, 69) and 1 display questions (utterance 56).

The question of checking students understanding can be answered well by students. They understand how the expression of saying sorry in formal and informal occasion. It is because they are quite familiar with the expression.

\section{Exercising Exchange}

In this phase the teacher checks students understanding about how to say sorry and in what occasion those expression is suitable to apply. The exercising phase comprise of 1 display questions (utterance 56), 3 referential questions (utterances 58, 62, and 69).

From the discussion and complete result of type and the calculation of teachers' questions for scaffolding students in order to give students more understanding toward the text and teachers are very clever arranging questions to guide students to achieve the aim.

During the teaching and learning process, teacher proposed 24 questions. Among those numbers, 16 of them are epistemic questions and the rest is echoic questions. It means that the 
teacher apply questions more on the material and learning experience than question for organizing learning.

Furthermore, echoic questions consist of 8 questions which 7 of them are checking student understanding and 1 for confirmation. All of the teachers' question will be elaborated as follows:

\begin{tabular}{|l|l|l|l|l|l|c|}
\hline $\begin{array}{l}\text { Types of } \\
\text { Question }\end{array}$ & $\begin{array}{l}\text { Preparation } \\
\text { and } \\
\text { Apperception }\end{array}$ & $\begin{array}{l}\text { Teachers' } \\
\text { Explanation }\end{array}$ & $\begin{array}{l}\text { Checking } \\
\text { students' } \\
\text { understanding }\end{array}$ & $\begin{array}{l}\text { Difficult } \\
\text { word } \\
\text { discussion }\end{array}$ & Exercise & Total \\
\hline Echoic & 7 & 3 & 4 & & & 7 \\
\hline a. Comp & & & & & & \\
\hline b. Clarf & & 1 & & & & 1 \\
\hline c. Conf & & 1 & 3 & & 3 & 7 \\
\hline Epistemic & & 7 & 1 & & 1 & 9 \\
\hline a. Ref & & & & & & \\
\hline b. Display & & & & & & \\
\hline c. Assert & & 12 & 8 & & 4 & 24 \\
\hline d. Rhetoric & & & & & & \\
\hline \multicolumn{1}{|c|}{ Total } & 7 & & & & & \\
\hline
\end{tabular}

Based on the data above, we can see that epistemic question reach $66,6 \%$, while echoic questions attain 33,3 \%. Among the epistemic questions, 29,1 \% is referential questions and 37,5\% display questions. Moreover, from 33,3 \% of echoic questions, $29,1 \%$ is checking for students understanding and, $4,2 \%$ of confirmation question.

In line with discussion above, the domination of epistemic question $(66,6 \%)$ is the fact that teacher tries to concentrate to the material of teaching and learning experience. Whereas the domination of display question showing that the teacher emphasize on discussion of teaching material, while the large number of referential question percentage is sign that teacher try to collaborate lesson with students experience.

\section{CONCLUSION}

This study reveals that epistemic questions are more dominant than echoic questions. This study also reveals that three teachers use various techniques to modify questions when their question cannot generate students response. Those techniques are repeating, rephrasing, giving additional questions. Teachers model of teaching determine students model of learning. The composition and proportion of questions, assignment and teacher explanation are one of the important key in stipulating the success of establishing the language competence. The establishment of language competence and positive attitude, autonomous and responsible are to achieve leading individual.

\section{REFERENCE}

Adibah. (2011). An analysis of questions used by English teacher in classroom (A case study at the 10th grade of SMA Al -yasini Pasuruan 2011/2012).

Akmaludin. (2009). Types of teacher Questions and Students Responses in EFL Clasroom Activities. Unpublished Thesis UPI Bandung. 
Alwasilah, A.C. 2008. Pokoknya Kualitatif. Dasar-Dasar Merancang dan Melakukan Penelitian Kualitatif. Jakarta:PT. Dunia Pustaka Jaya.

Behnam,B \& Pouriran, Y. (2009). Classroom Discourse: Analyzing Teacher/Leaner Interactions in Iranian EFL Task-based Classrooms. Porta Linguarum 12, Junio 2009.

Brown, H.D. (2001). Teaching by Principle. An interactive approach to language pedagogy. Englewoo Cliffs: Prentice Hall.

Brown G.D. \& Edmudson. R. (1984) Asking Question. Wragg.EC. (Eds.) Clasroom teaching Skills. Great Britain: Billing and Sons Limited, Worcester.

Cakmak, M. (2009). Pre-service Teachers' thought about teacher questions in effective teaching process. Elementary Education online, 8 (3), 666-675, 2009.

Chaudron, C. (1988). Second Language Classrooms: Research on Teaching and Learning. Cambridge: Cambridge University Press.

Chaudron, C. (1998). Second language classroom: Research on teaching and learning. Cambridge: Cambridge university press.

Chaudron, C. (2001). Progress in Language Classroom Research: Evidence from the modern language journal, 1916-2000. The Modern language Journal, 81, (i), 57-76.

Chin, C. (2006). Classroom Interaction in science: Teacher questioning and feedback to students responses. International Journal of science education 28, (1), 1315-1346.

Chun-miao,X. (2007). A study of teacher questioning in interactive English classroom. Sino-US English Teaching, 4, (4), 29-37.

Cohen , L.and Manion, L. (1994). Research Method in Education. $4^{\text {th }}$ Edition. London:Routledge 11 New Fetter Lane.

Darn, S. (2008). Asking questions. Retrieved on Januari 152010 from http://www. Teachingenglish.org.uk/think/articles/asking-questions.

Ellis, R. (1986). Understanding Second Language Acquisition. Oxford:Oxford University Press.

Ellis, R. (!994a). The second Language Acquisition. Oxford. Oxford University Press.

Ellis, R. (1997). Second language Acquisition. Oxford: Oxford University Press.

Emilia, E. (2005). A Critical Genre-Based Approach to Teaching Academic Writing in a Tertiary EFL Context in Indonesia, unpublished Ph.D thesis, volume 1, Australia: Department of Language, Literary art education. Faculty of Education. The University of Melbourne.

Eng Ho, D.G. (2005). “Why do Teachers Ask the Question they ask?”, RELC Journal, 36, 297-310.

Harmer, J. (1991). The Practice of English Language teaching. New Edition Completely revised and Updated. Malaysia:pearson Education Limited.

Harmer, J. (2001). The Practice of English language teaching. Forth edition. UK: Pearson EducationLimited.

Harmer, J. (2007). The Practice of English Language Teaching (fourth ed.). England: Longman.

Hassan Qashoa, S. (2012). Effect of teacher question types and syntactic structures on EFL classroom Interaction.The international Journal of social Sciences 30th January 2013 Vol.7 No.1.

Hussin,H. (2006). Dimensions of Questioning: a qualitative study of current classroom practice in malaysia. TESL-EJ september 2006 volume 10, number 2.

Inan, B \& Fidan D. (2012). Teacher questions and their functions in Turkish as a foreign Language (TFL) classess. Procedia-social and behavioral sciences 70 (2013) 10701077.

Johnson, K. (2001). An Introduction to Foreign Language Learning Teaching. Pearson Education Limited.

Lincoln, Y.S. \& Guba, E.G. (1985). Naturalistic Inquiry. Beverly Hills: Sage Publication.

Long, H.M. (1981). Input, interaction, and second language acquisition. Annals New York Academy of science, 295-278.

Merriam, Sharan B. 1998. Qualitative Research and Case Study Application in Education. San Fransisco:Jossey-bass publishers. 
Nunan, D. (1991). Language Teaching Methodology A Textbook for Teacher. London: Prentice Hall international (UK) Ltd.

Nunan, D. (1992).Research Method in Language Learning. United States of America: Cambridge University Press.

Ornstein, A.C. (1987). Questioning: The essence of Good teaching. NASP Bulletin, 71;71-79.

Pica, T.et al. (1987). The Impact of Interaction of Comprehension. TESOL QURTERLY. 21,(4).

Roostini, Kasih E. 2011. A Reflection on Teacher Questioning Types. Conaplin Journal Indonesian Journal of Applied Linguistics, Vol. 1 No. 1 (July 2011).

Ruby Yang, Chi C. 2010. Teacher Questions in Second Language Classrooms: an investigation of three case studies. Retrieved on 20 of July 2013 at http://asian-efljournal.com/quarterly journal/2010/03/25/teacher-questions-in-second-languageclassrooms-an-investigation-of-three-case-studies/.

Silverman, D (2005) Doing Qualitative Research. $2^{\text {nd }}$ Edition. London: Sage Publications, Inc

Suherdi,D. (2009). Classroom Discourse analysis: A systemiotic approach. Bandung: UPI press.

Suherdi, D. (2009). Mikroskop Pedagogik, alat analisis proses belajar mengajar. Bandung: UPI press.

Thornburry, S. (1996). Teacher Research Teacher Talk. ELT Journal, 50, 279-289. 